\title{
Innovation for New Anaerobic Domestic Wastewater Treatment Recycling System in Developing Countries
}

\author{
Florence Dennis Uzuh ${ }^{1, *}$, Hideaki Toyoda², and Sayaka Matsubara² \\ ${ }^{1}$ National Metallurgical Development Centre, Jos, Nigeria \\ ${ }^{2}$ Kansaikako Co., Ltd. Osaka, Japan
}

${ }^{*}$ Corresponding author: Florence Dennis Uzuh, National Metallurgical Development Centre, Jos, Plateau State, Nigeria, E-mail: florenceuzuh@ gmail.com

Received: 08 Apr, 2019 | Accepted: 29 May, 2019 | Published: 04 Jun, 2019

Citation: Uzuh FD, Toyoda H, Matsubara S (2019) Innovation for New Anaerobic Domestic Wastewater Treatment Recycling System in Developing Countries. Int J Water Wastewater Treat 5(1): dx.doi.org/10.16966/2381-5299.159

Copyright: (C) 2019 Uzuh FD, et al. This is an open-access article distributed under the terms of the Creative Commons Attribution License, which permits unrestricted use, distribution, and reproduction in any medium, provided the original author and source are credited.

\begin{abstract}
Over the years, the spate of water pollution has assumed an alarming dimension globally because of rapid urbanization, aggressive economic development and geometric population growth. This has given rise to acute shortage of freshwater resources. The need for appropriate and efficient treatment technologies to achieve effluent quality that complies with acceptable standard has become imperative. Conventional wastewater treatment technologies are not only costly to build, but also have combined functional and maintenance problem. As a result, forward-looking innovative technologies which are cost effective such as Domestic Multi-Recycler (DMR) is desperately needed to restore poor water pollution that poses serious health threat to most people in developing countries and to improve the soundness of water and wastewater recycling system. Also enhance the quality of treated water discharged from the source to the municipal in a wastewater treatment method anaerobically without requiring electricity and the sludge generated is utilize as fertilizer. Since functional wastewater collection and treatment are of vital importance from the perspective of both environmental and public health. In this paper, the technology application is aimed at contributing immensely to attain goal 6 of sustainable development goals (SDGs). "Ensuring availability and sustainable management of clean water and sanitation for all."
\end{abstract}

Keywords: Innovative; SDGs; DMR; Anaerobic; Developing countries; No electricity

\section{Introduction}

In recent times, relative amount of the wastewater produced by community wastewater management and sewer systems in most developing countries are not treated. The continuous discharge of human, industrial and agricultural wastewater into the environment has drastically reduced the global scale of freshwater resources. Domestic wastewater treatment is targeted to curtail the number of excreted pathogens to low levels and subsequently the risk of further environmental transmission of emerging diseases are extensively reduced. New Innovations and appropriate technologies have contributed to wastewater treatment and reuse that are currently accepted in order to protect the environment, human being and animal health [1].

Generally, untreated wastewater contains high proportion of organic material, toxic compounds, as well as nutrients and numerous pathogenic microorganisms. To mitigate the environmental and public health hazards associated with wastewater, it must be subjected to adequate treatment before disposal. Advances in water research have led to highly efficient, diverse and eco-friendly methods of domestic and industrial wastewater treatment
[2]. Therefore, it is of significant importance to both treat the wastewater and select wastewater treatment processes that reduce pathogen while retaining nutrients if the water is to be applied for irrigation purposes [3].

Cost may be a major determining factor, especially in developing countries. Water treatment is expensive, and this cost increases with the efficiency of the process and quality of effluent. Estimation of cost is strenuous and even costly in itself, because of a large number of parameters involved and the fact that those parameters are usually unclear until the design process is underway [4]. Amidst the possible treatment alternatives for wastewater from the households and industries, anaerobic processes stand out as potentially effective choices. They offer a number of advantages over traditional aerobic processes, namely
1. Low Energy Demand
2. Lower Sludge Formation
3. Low Nutrient Demand and
4. Energy Recovery [5] 
Anaerobic biological degradation processes, constitute the ideal route to a sustainable protection of the environment when properly integrated with complementary biological and physical methods [4].

Numerous technique have been developed to stabilize anaerobic biomass within bioreactors while at the same time, preventing loss of microorganisms in the effluent stream, which may reduce the process rates and as such tends to lower the growth of anaerobic microorganisms, which takes longer time than aerobic treatment [6].

The use of anaerobic process for domestic wastewater treatment would achieve lower carbon footprint as it eliminates aeration and generate methane. Among several anaerobic treatment processes, high rate anaerobic digesters receive great attention due to its high loading capacity and chemical oxygen demand removal rate. Up-Flow Anaerobic Sludge Blanket Reactor (UASB) is getting wide acceptance. However, its application is still limited to industrial wastewater treatment. Despite its efficiency in wastewater treatment, the UASB reactor has not gained acceptance in developing countries [7].

The Upflow Anaerobic Sludge Blanket (UASB) reactor is a promising alternative for house-on- site treatment of domestic wastewater designed to overcome the inherent weaknesses of the conventional septic tank [8]. The most commonly used bioreactors for this purpose are hybrid reactors, such as the combination of a UASB and bio-filter, where the granular sludge bed is associated with bacterial colonies on particles of support material [6]. On an industrial scale, it has also found wide acceptance because of low sludge production, possibility of energy recovery, low hydraulic retention time (HRT) and high solids retention time. It is by far the most widely used anaerobic reactor for the treatment of industrial wastewater [9].

Decentralized, on-site application of anaerobic treatment for communities or individual households may thus provide combined wastewater management, energy production, and nutrient recovery since anaerobic treatment stabilizes the treated wastewater, and enables production of renewable energy (methane, hydrogen), and preservation of valuable resources (nutrients) [10]. Due to low construction, operation and maintenance costs, small land requirement, low sludge is generated as well as production of biogas. High-rate anaerobic systems represent low-cost and sustainable technology for domestic sewage treatment.

Despite the successes recorded in the anaerobic treatment of wastewater, the UASB reactor has not been very efficient in countries with low to moderate temperatures. At such temperature, the chemical oxygen demand (COD) removal is limited and a long hydraulic retention time (HRT) is needed for one-step system for providing sufficient hydrolysis of particulate organics [11]. Domestic wastewater has generally low concentration of chemical oxygen demand (COD) and relatively high concentration of suspended solids with low specific methane yield that requires initial hydrolysis to convert the suspended solids into soluble substrate. Hydrolysis is often the limiting step, especially at low temperature conditions [12].

The establishment of SDG 6, Ensure availability and sustainable management of clean water and sanitation for all, mirrors the increased investigation on water and sanitation issues related to global political agenda. SDG 6 includes eight global targets that are widely relevant and objective. They cover the whole water cycle including: providing access to safe drinking water (target 6.1) and sanitation and hygiene services (6.2), reuse and treatment of wastewater and improve ambient water quality (6.3), water-use efficiency and scarcity (6.4), implementing integrated water resources management (IWRM) through transboundary cooperation as appropriate (6.5), protecting and restoring water-related ecosystems (6.6), international cooperation and capacity-building (6.a) and participation in water and sanitation management (6.b). Target (6.3) reuse and treatment of wastewater and improve ambient water quality comprises of collecting, treating and reusing wastewater from households and industry, reducing diffuse pollution and improving water quality are major challenge for the water sector [13]. However, to disseminate the sewerage treatment system in developing region with fiscal foundation, it is not enough to transfer the existing technology activated sludge law of Japan as it is, but sewage treatment systems that can fit into the regional, social and economic structure, self-sustainable, creation of low-cost, simplified anaerobic processing technology suitable for actual situation required in developing countries specification.

The main objective of this research is innovating new anaerobic domestic wastewater treatment recycling system such as domestic multi-recycler (DMR). DMR uses microorganisms to treat wastewater without the use of electricity. A simple domestic treatment method of wastewater from toilet, bathroom, kitchen and sewage of community. The treated water is used for irrigation, and the sludge generated by anaerobic treatment is composted and used as an organic fertilizer. One of the advantages and features of DMR is its recycling process. After the treatment of wastewater, the sludge generated from DMR is composted with organic waste from households, food processing and agricultural waste, mix together with anaerobic sewage with other garbage, which contains valuable plant nutrients, rich in nitrogen and phosphorus such compost is used as an organic fertilizer by farmers. Asides providing plant nutrition, the organic substances contained in compost improve soil humus content.

\section{Brief Summary of wastewater treatment and reuse in Japan}

Japan, Germany, Netherlands, USA and India are the leading countries in anaerobic wastewater treatment with $162,115,92,83$ and 79 anaerobic treatment facilities, respectively [14]. Japan is still leading in membrane technologies that have led to the development of on-site wastewater treatment units capable of water-reclamation quality effluent [15]. Currently, membrane technology is one of the water-saving as well as earthquake-resistant and leak proof. As a result, the country is highly-efficient in water resource management and has achieved global leadership in water technology. The recovery rate of industrial water has increased to nearly 80 percent, while the leakage rate of water supplies is kept at less than 10 percent. Japan's technology and experience constitutes a remarkable strength, and it can contribute to the world by expanding its water-related businesses internationally. The establishment of efficient water management systems through advancements in water-saving technology has supported Japan's economic growth.

The word Johkasou in Japanese language is an on-site wastewater treatment; it is a combination of the words jouka, which means purification, and sou, meaning tank or tub. Johkasou are mainly used in two situations:

(1) When there is no access to sewers and

(2) In high population density areas for on-site wastewater treatment including water reclamation.

Until World War II, Japan's economic was broadly based on rice agriculture. The most common type of waste treatment as at then was vault toilets (pit latrines), with the night soil collected for use as soil conditioners and soil fertilizers. Following World War II, flush toilets were rapidly introduced throughout Japan. Rapid industrialization post-world war II catalyzed massive rural-urban migration, giving 
rise to serious challenges associated with water and sanitation. Figure 1 shows a typical process flow for a household Johkasou. The transformation from vault toilets (pit latrines) to Johkasou gave rise to facilitate the introduction of flush toilets.

In view of this, sewers and Johkasou have developed side by side as of the year $2000,71 \%$ of household wastewater in Japan were receiving some type of treatment and $91 \%$ of Japanese residents had flush toilets [15]. As at the year 2017, wastewater treatment distribution is as shown in figure 2 below [16].

Japan has crucial experience in construction of sewerage and development of sewer network at the same time having good maintenance of it in a short period. Japan has constructed and maintained sewerage facilities with state-of-the-art technology, especially, such as advanced treatment, urban storm water control (measures for intensified heavy rain), Combined Sewer Overflow (CSO) control, wastewater reuse, recycling of sludge as resources (sludge carbonization), energy-saving treatment and rehabilitation/ renewal of facilities [17].

\section{Material and Methods}

\section{The structure and working principle of DMR}

DMR as the name implies is environmentally friendly. It can be referred to as non-electric Johkasou. It is a recent innovation of Kansaikako Co., Ltd. Japan, an anaerobic treatment method. DMR has anaerobic filter bed tanks, which are separated into two or more anaerobic treatment rooms and connected in series from figure 3, each of which is filled with an original filter material. The first room which is approximately one-half to two-thirds of the effective capacity of the anaerobic filter bed. The anaerobic filter media is coarse, removes suspended matters and anaerobic microorganisms purify dirt (organic matter) in the wastewater which makes it easy to trap, filter the solid matter and prevent water flow in an anaerobic filter bed structure from malfunctioning due to its durability. The specific surface area of the filter media is $107 \mathrm{~m}^{2} / \mathrm{m}^{3}$. The second room uses the difference size filter media. Its specific surface area is $208 \mathrm{~m}^{2} / \mathrm{m}^{3}$. So, more microorganisms will be attached to it. The effective water depth of each room is not less than $1.2 \mathrm{~m}(1.5 \mathrm{~m}$ if the number of capacity of persons to be treated is more than 10 people). A sludge cleaning hole having a circular diameter of 15 centimeters or more inscribed in the filter material, which is not likely to be blocked in the tank, as such maintaining the distance of the bottom of the tank properly and effective extraction of floating materials and sludge in each room. The headspace of the DMR is vented to the atmosphere and not completely sealed.

The DMR which has an anaerobic filter beds with filter material which removes suspended matter (solid matter) contained in wastewater and anaerobic microorganism (bacteria and protozoan organism). Sewage is transferred from the first room to the second room for further purification. While Johkasou uses aerobic microorganisms with the aid of blower for aeration, DMR does not require aeration, and therefore electricity is not required. In the wastewater treatment method, the biological activated carbon tank is a tank filled with activated carbon for filtration, and needs to be reactivated annually. The solid-liquid separation tank enhances the performance of wastewater discharged and released the treated water flowing into the biological activated carbon tank which has fine floc and sludge is clearly separated. The DMR removes approximately $80 \%$ of Biochemical Oxygen Demand (BOD) in the first and second anaerobic room. The remaining $10 \%$ is treated with biological activated carbon, whereby the activated carbon absorbs and removes the soluble BOD.
The treated water which is the supernatant of the solid/liquid separation tank flows into the biological activated carbon tank, the BOD contained therein adsorbs to the activated carbon. The treated water discharged from the biological activated carbon tank passes through the chlorine agent, where it is hygienically treated and discharged outside of the tank. The BOD concentration of the final treated water is below $20 \mathrm{mg} / \mathrm{L}$.

\section{Description of label symbols of DMR}

1. Sewage inlet

2. Anaerobic filter tanks

3. Solid liquid separation tank

4. Biological activated carbon tank

5. Disinfection tank

6. Treated water discharged port (Figure 3)

\section{Anaerobic filter tank}

The anaerobic filter media is made of polypropylene, also used for aerobic /anaerobic filter bed, deodorizing filler and fishing reef. From figure 5, (Left) media for the first anaerobic tank specific surface is $\varnothing 100: 107 \mathrm{~m}^{2} / \mathrm{m}^{3}$, (Right) dense media for the second anaerobic tank specific surface is $\varnothing 70: 208 \mathrm{~m}^{2} / \mathrm{m}^{3}$. $\varnothing 70$ has outstanding ability to trap solids and maintain anaerobic microorganisms. Suspended solids are removed and anaerobic treatment is carried out efficiently.

These anaerobic filter media can be used semi-permanently and does not require replacement periodically. The pump out frequency of inert solids is done annually for composting. It is the same frequency with Johkasou. However, the volume of sludge generated from DMR is less than that of Johkasou. Johkasou uses the aerobic treatment method. The amount of sludge generated by anaerobic microorganisms is 10$20 \%$ of the amount of sludge generated by aerobic microorganism. After sludge is pumped out from DMR, it is converted to an organic fertilizer in a composter. In Japan, sludge from Johkasou is incinerated, it incurs high cost and not eco-friendly.

\section{Installation and testing}

DMR was installed at the house of the village headman in Eklara (Gujarat). Rainfall is low, so they have insufficient water for agriculture, and average temperature is over $20^{\circ} \mathrm{C}$ in that region. Figure 6 shows that the outer tank was made of concrete structure and need to be coated to prevent it from being exposed to acidic conditions both in the liquid and in the headspace.

Treated water was discharged into the municipal for irrigation purpose. Samples of treated wastewater were withdrawn at three different consecutive times for three months after DMR was installed at village of the headman in Eklara (Gujarat). From table 1, samples were analyzed in the laboratory employing the following methods by Bureau of Indian Standards (BIS). BOD was determined according to IS 3025 (Part 44). Chemical oxygen demand (COD) IS 3025 (Part 58). Non-filterable residue (Part 17). Total suspended solids (TSS) IS 3025 (Part 34). Nitrogen (Part 34). Oil and Grease IS 3025 (Part 39).

\section{Results and Discussion}

\section{DMR results in India}

Treated water quality parameters from DMR were certified in all eight provincial government drainage regulations and standards in India. Table 1 describes the main water quality parameters of the new anaerobic domestic wastewater treatment recycle system 


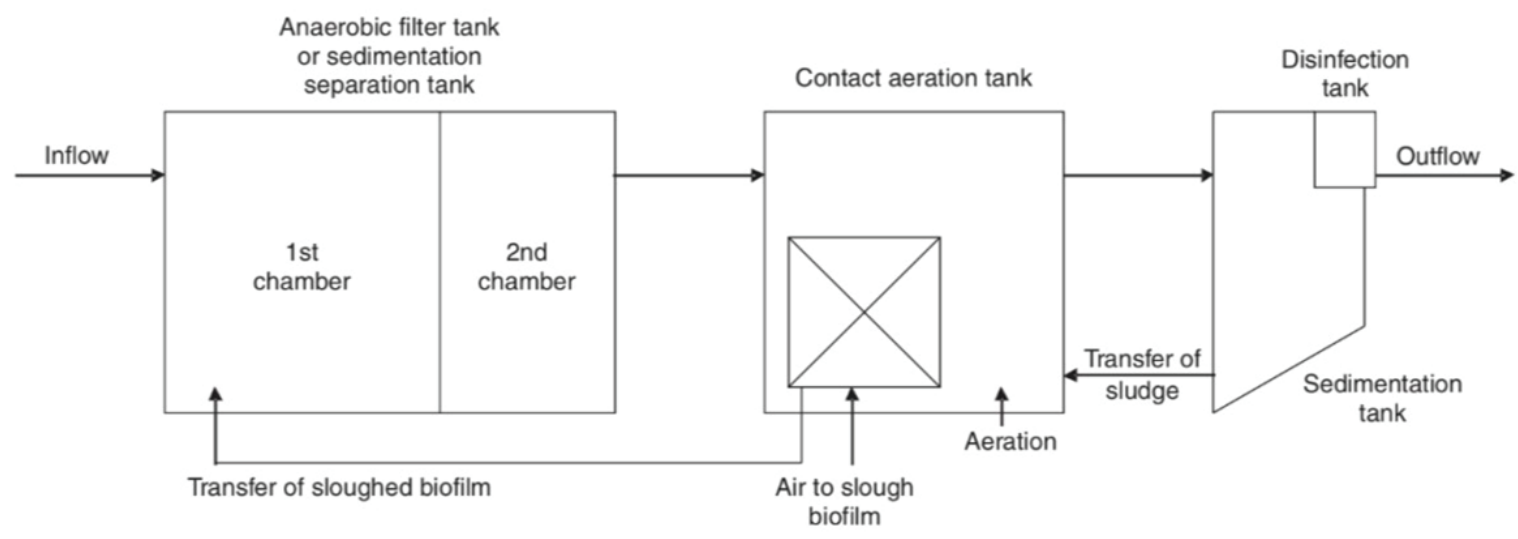

Figure 1: Schematic diagram of a typical process flow for a household Johkasou [15].

Wastewater treatment distribution in 2017

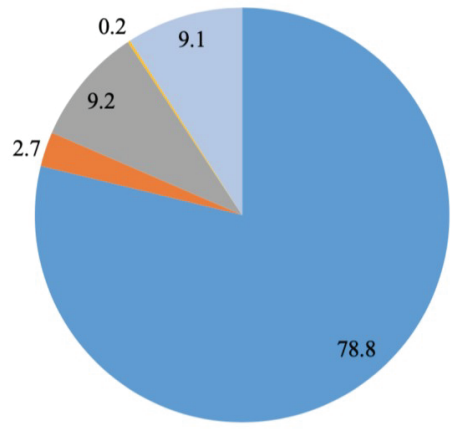

$$
\begin{aligned}
& \text { - Sewer system } \\
& \text { n Septic tank } \\
& \text { - Others }
\end{aligned}
$$$$
\text { n Agricultural collection and discharges }
$$

- Community sewage treatment facility

Figure 2: Wastewater treatment distribution in Japan, 2017.

demonstration test results. The influent and effluent $\mathrm{BOD}_{5}$ were 67 \pm 17 and $5.0 \pm 1.4 \mathrm{mg} / \mathrm{L}$ respectively. The effluent $\mathrm{BOD}_{5}$ is clearly below the Indian effluent discharge standard of $30 \mathrm{mg} / \mathrm{L}$ for $\mathrm{BOD}_{5}$. The influent and effluent $\mathrm{COD}_{\mathrm{Cr}}$ were $202.3 \pm 28.3$ and $22.0 \pm 9.4$ $\mathrm{mg} / \mathrm{L}$ respectively. The effluent $\mathrm{COD}_{\mathrm{Cr}}$ is clearly below the Indian effluent discharge standard of $250 \mathrm{mg} / \mathrm{L}$ for $\mathrm{COD}_{\mathrm{Cr}}$. The influent and effluent TSS were $1200 \pm 184$ and $8 \pm 4 \mathrm{mg} / \mathrm{L}$ respectively. Since domestic wastewater consists of both night soil and gray water. The effluent TSS is clearly below the Indian effluent discharge standard of $100 \mathrm{mg} / \mathrm{L}$ for TSS. The influent and effluent Ammonia were $8 \pm$ 0 and $5 \pm 0 \mathrm{mg} / \mathrm{L}$ respectively. The effluent Ammonia shows clearly below the Indian effluent discharge standard of $50 \mathrm{mg} / \mathrm{L}$ for $\mathrm{BOD}_{5}$. Oil and grease influent $25 \pm 16 \mathrm{mg} / \mathrm{L}$ effluent were not detected (ND) and the effluent discharged standard of $10 \mathrm{mg} / \mathrm{L}$ for oil and grease. $\mathrm{N}$-hexane concentration in the influent is less than $30 \mathrm{mg} / \mathrm{L}$, this is due to biodegradation by anaerobic microorganisms.

Therefore, the discharged water quality (treated water) showed good values for the concentration of inflow water, and fluctuation of flow rate and the variation of standard deviations value were also small. The $\mathrm{BOD}_{5}$ intermediate was $19.8 \mathrm{mg} / \mathrm{L}$ for the former and $5.0 \mathrm{mg} / \mathrm{L}$ for the latter while the planar catalytic oxidation filter bed treated water and the discharge water of the TSS were the same $8 \mathrm{mg} / \mathrm{L}$. This suggests that organic decomposition performance of microorganisms by biological activated carbon in the latter stage filtration tank is superior. This demonstration test illustrates that the quality of the treated water of BOD is below $5-20 \mathrm{mg} / \mathrm{L}$. This is assumed to be contributed to India's temperate climate with an average temperature of $27^{\circ} \mathrm{C}$.

The processing tank used in this demonstration test had an effective capacity of the domestic treatment tank can be treated at about 1.9 $\mathrm{m}^{3}$. This was about $1 \mathrm{~m}^{3}$ less than the effective capacity of a fiveperson compacted muffler treated tank of Japan's structural standard type, compare to the basic unit of wastewater volume and wastewater concentration of households in India.

\section{Validation of optimized Procedure}

Inflow BOD: $183 \mathrm{mg} / \mathrm{L} \pm 18 \mathrm{mg} / \mathrm{L}$

- $\quad$ Inflow: $1.17 \mathrm{~m}^{3} \pm 0.26$

- The volume of anaerobic filter tank: $1.51 \mathrm{~m}^{3}$

- BOD volumetric loading: $0.174 \mathrm{~kg}-\mathrm{BOD} / \mathrm{m}^{3} / \mathrm{d}$

- Hydraulics Retention Time (HRT): 36 hours

This HRT is Japanese structural standard of anaerobic tank. Facultative anaerobic microorganism activity works for approximately 36 hours. Fermentation of methane does not occur much in the DMR, thus only little methane gas is generated. As such methane gas does not have impact on greenhouse gas emissions and carbon footprint, hence there is no need to be collected and stored.

\section{Influence of water temperature on the anaerobic treatment}

DMR treats wastewater by means of both anaerobic treatment and biological activated carbon treatment. From figure 7 shown above, water temperature, retention time and number of microorganisms greatly influence the treatment performance. The verification test of the DMR in Japan shows the relationship between water temperature and treated water. BOD concentration of the influent is $185 \mathrm{mg} / \mathrm{L}$, the influent volume is $1.2 \mathrm{~m}^{3} /$ day and the volume of anaerobic filter tank is $1.51 \mathrm{~m}^{3}$.

As a fundamental alternative water resource, wastewater can be used in agriculture to recoup for shortage. Wastewater irrigation has a long history of development and has undergone different phases in 

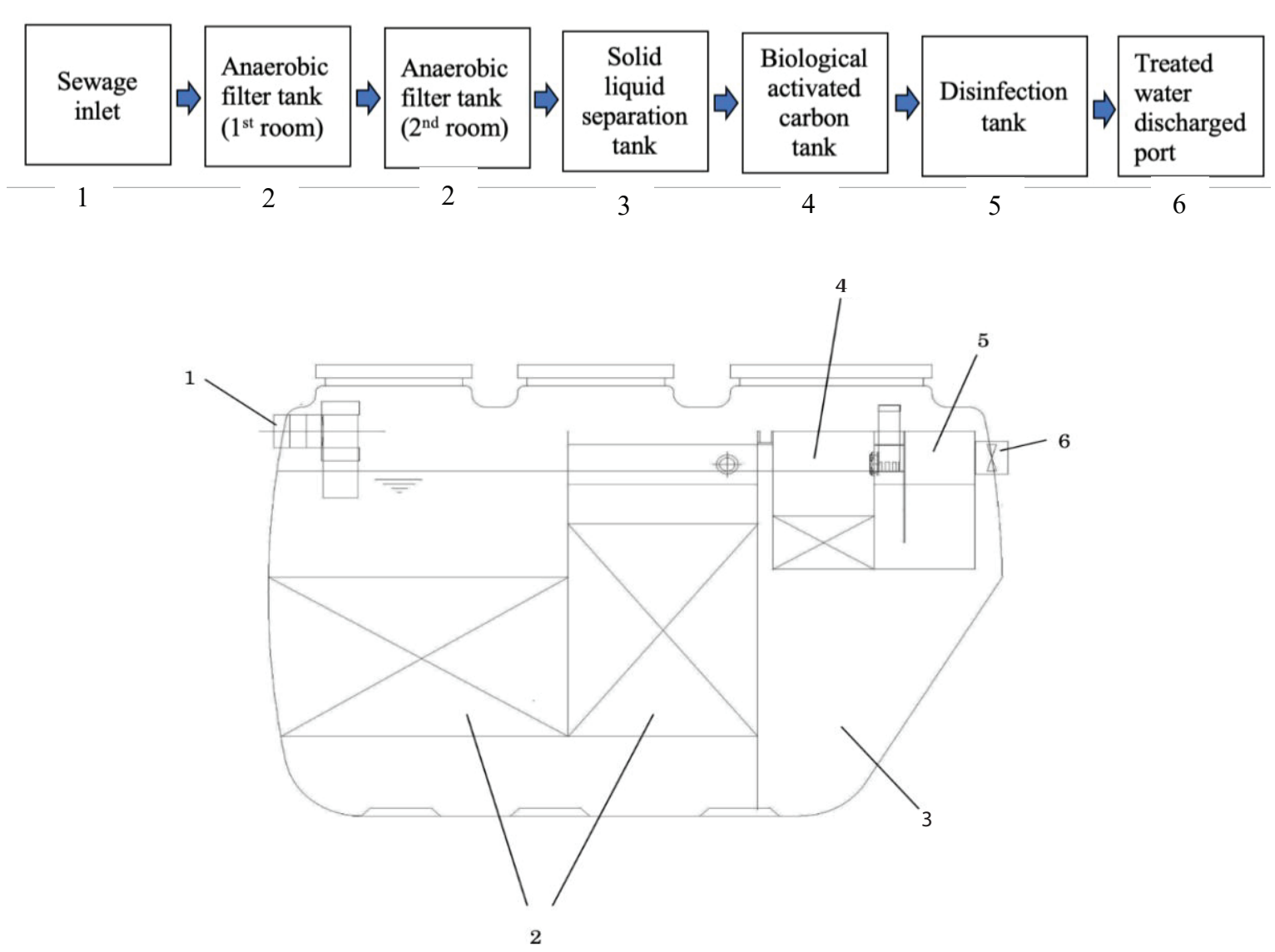

Figure 3: Flow chart and typical structure of domestic multi-recycler (DMR).
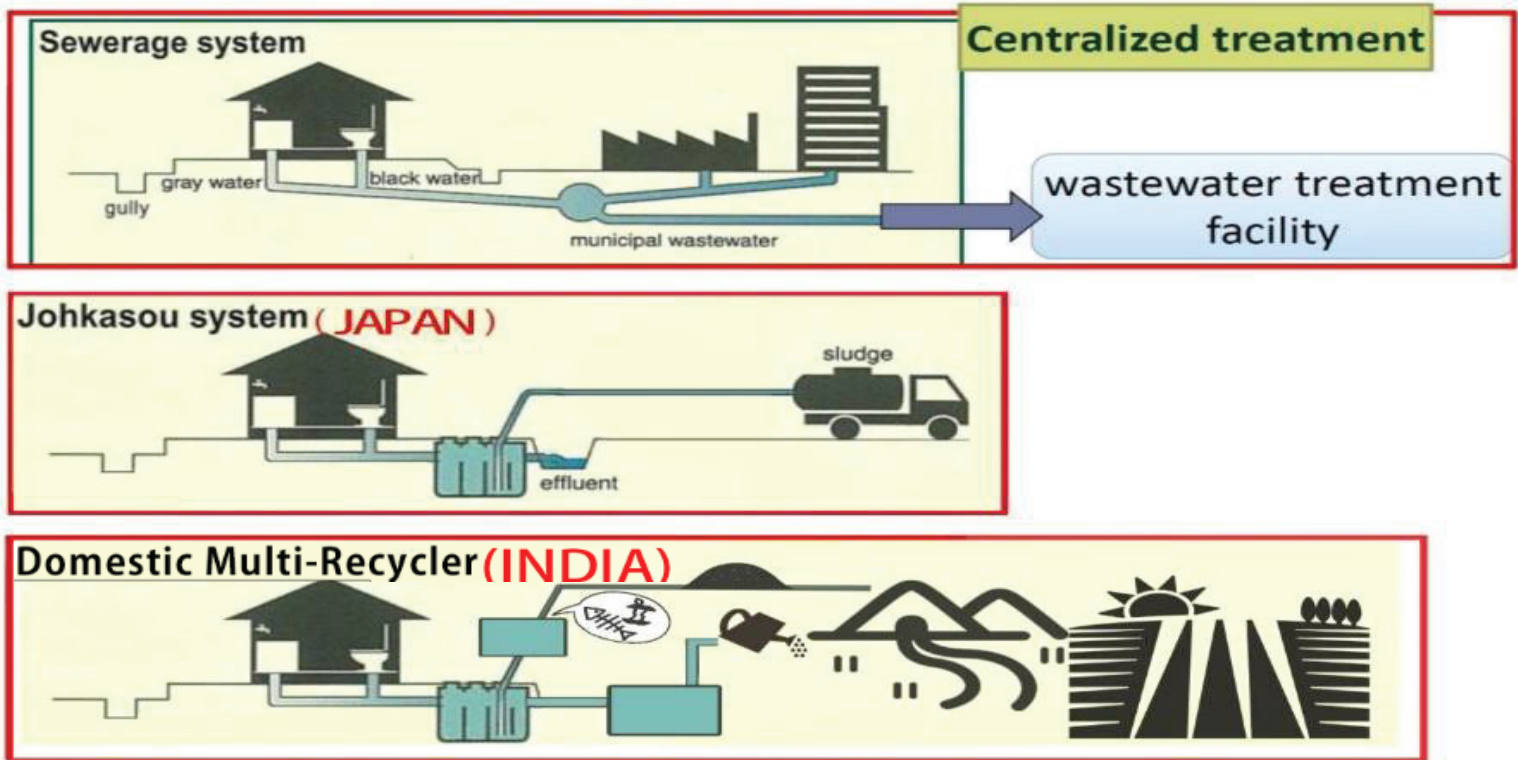

Figure 4: Schematic diagram of sewerage system, Johkasou and DMR.

https://www.jeces.or.jp/en/technology/index.html 
Table 1: DMR Performance Results.

\begin{tabular}{|c|c|c|c|c|}
\hline Parameter & Influent $\mathrm{mg} / \mathrm{L}$ & Effluent $\mathrm{mg} / \mathrm{L}$ & $\begin{array}{l}\text { The state Government drainage } \\
\text { standards. India } \mathrm{mg} / \mathrm{L}\end{array}$ & DMR \% removal efficiency \\
\hline (B.O.D.) @ 27 C & $67 \pm 17$ & $5.0 \pm 1.4$ & 30 & $92.5 \pm 3.8$ \\
\hline$\left(\mathrm{COD}_{\mathrm{Cr}}\right)$ & $202.3 \pm 28.4$ & $22.0 \pm 9.4$ & 250 & $89.1 \pm 5.6$ \\
\hline (TSS) & $1200 \pm 184$ & $8.0 \pm 4.0$ & 100 & $99.3 \pm 0.6$ \\
\hline Ammonia $\left(\mathrm{NH}_{4}-\mathrm{N}\right)$ & $18 \pm 10$ & $5.0 \pm 2.8$ & 50 & $72 \pm 11$ \\
\hline Oil \& Grease & $25 \pm 16$ & ND & 10 & $100 \pm 0.1$ \\
\hline
\end{tabular}

ND: Not Detected

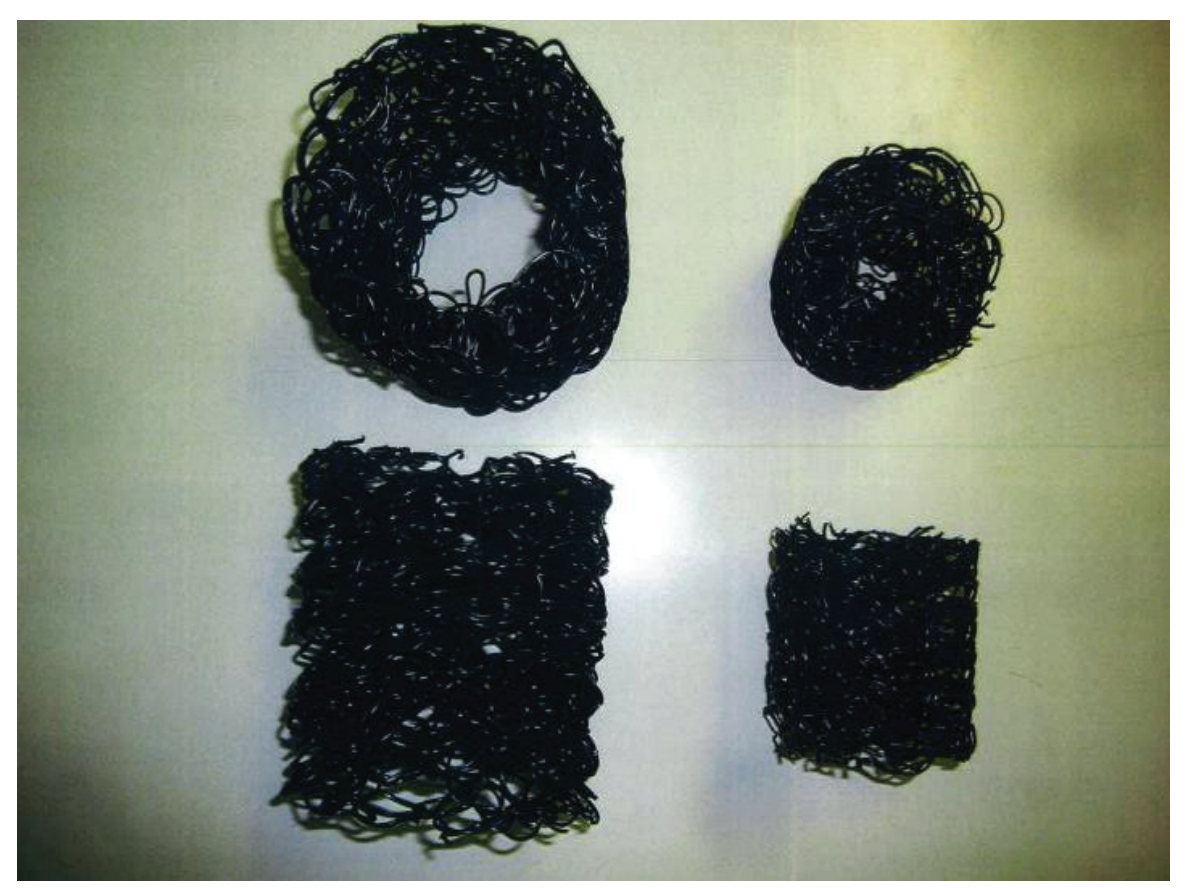

Figure 5: Anaerobic filter media.
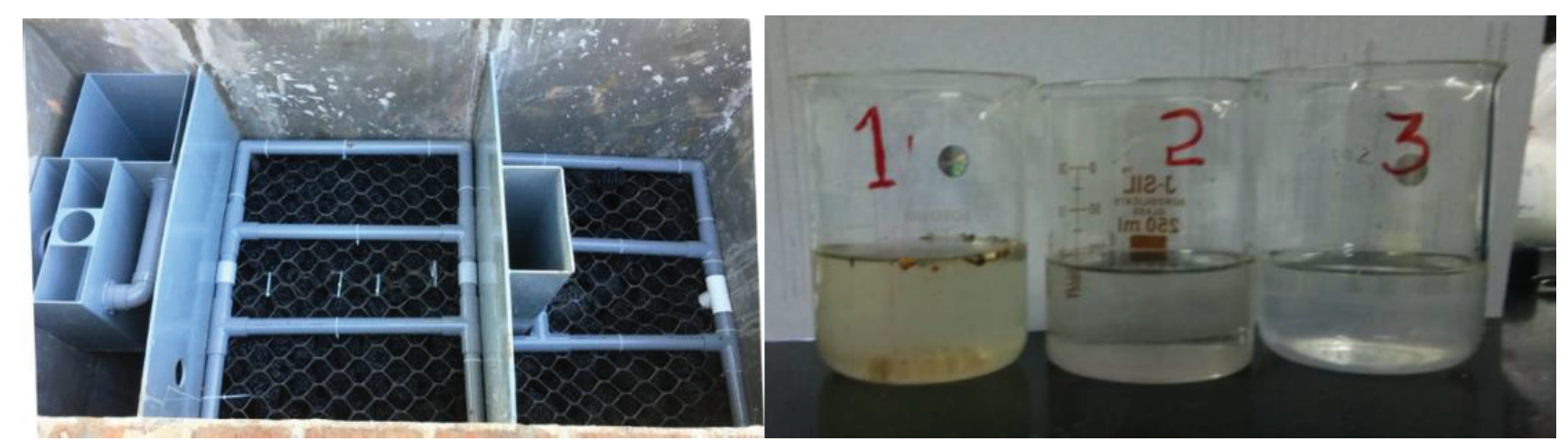

Figure 6: Constructed DMR and beaker 1, 2, 3 are Inlet, intermediate and outlet water respectively. 

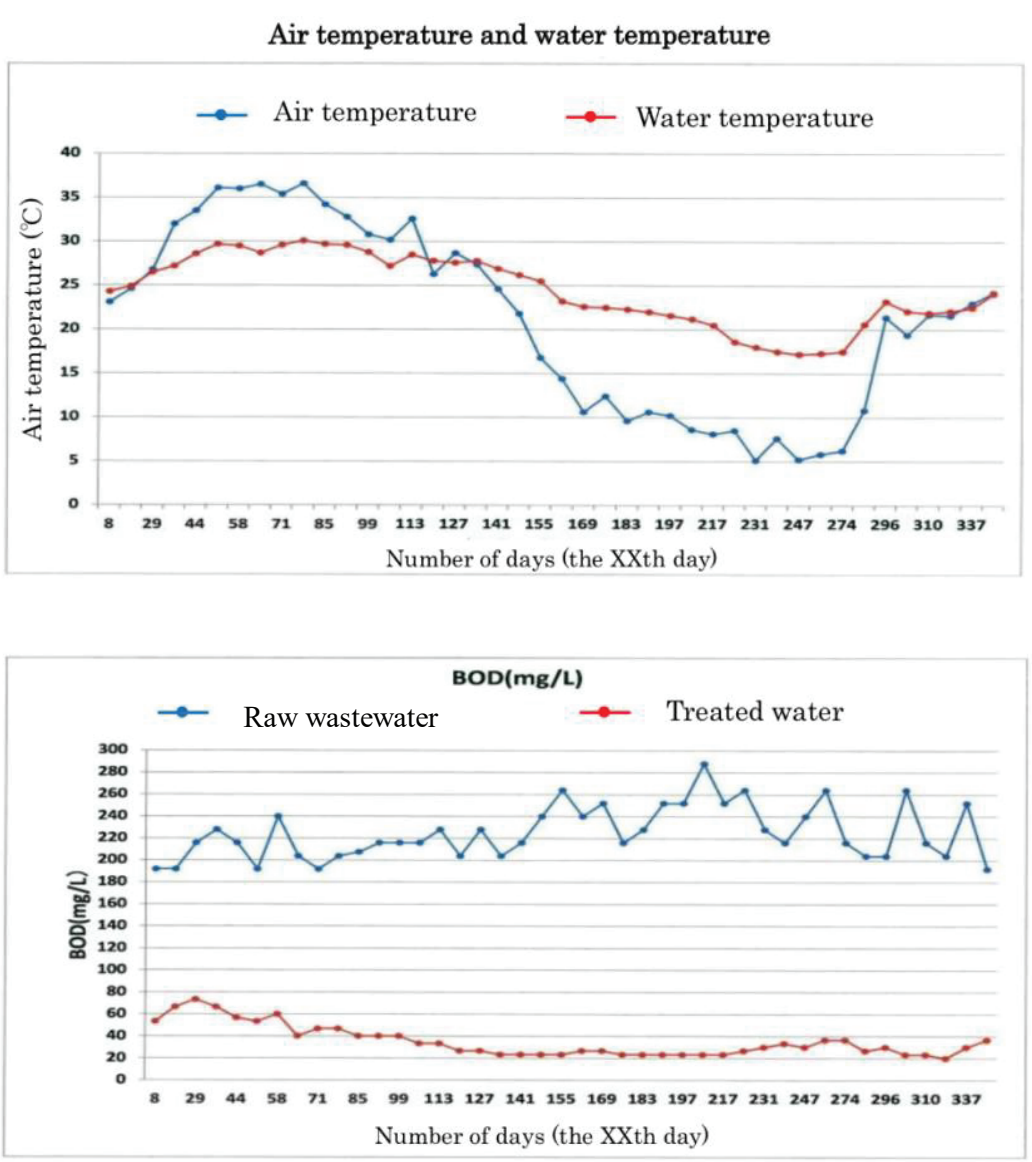

Figure 7: Air temperature, water temperature and BOD mg/L.

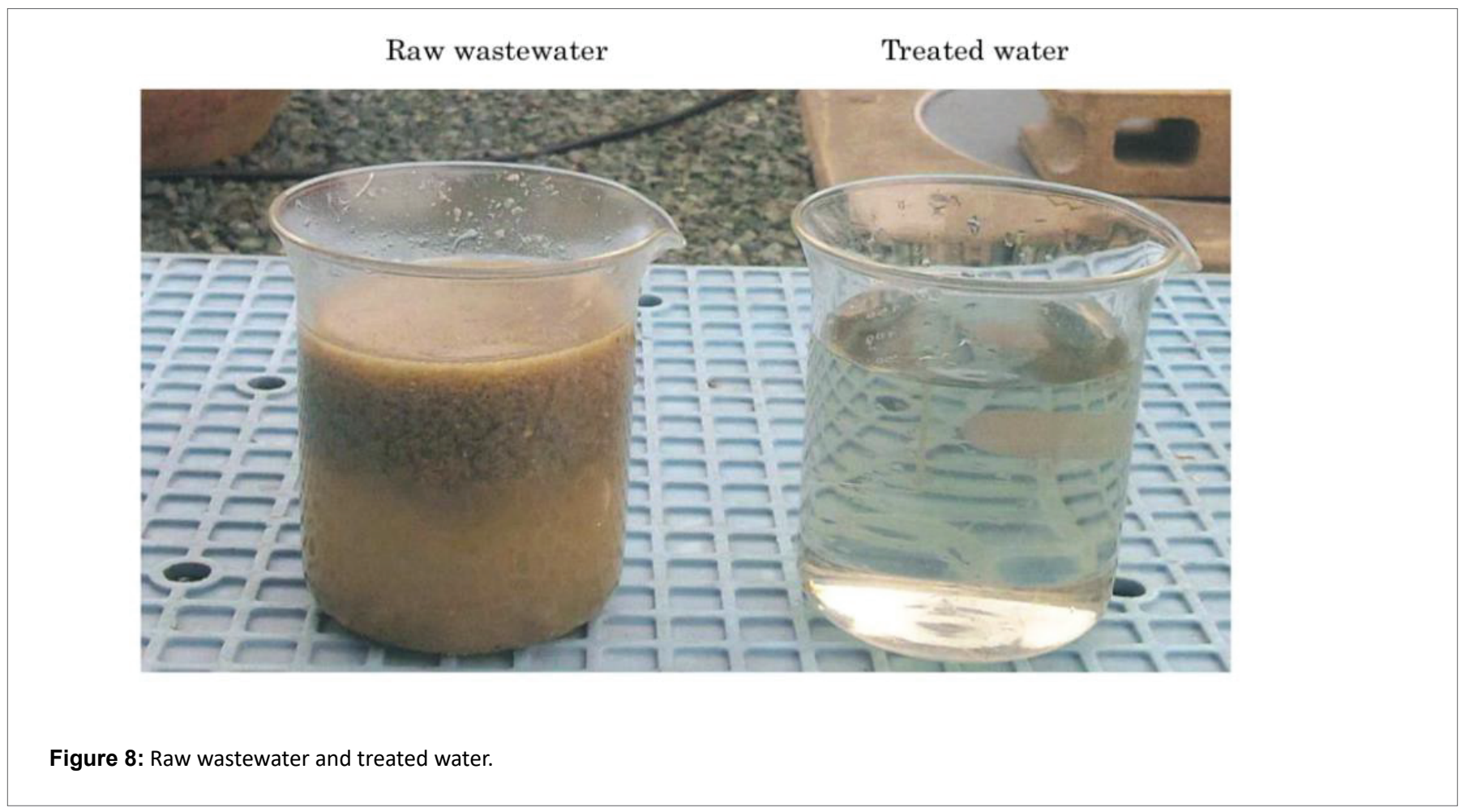


Table 2: Active ingredient content (reference value).

\begin{tabular}{|l|c|c|}
\hline & Anaerobic sludge & Treated water \\
\hline Nitrogen T-N (DS\%) & 6.0 & 6.5 \\
\hline Phosphorus $\mathbf{P}_{2} \mathrm{O}_{5}$ (DS\%) & 6.1 & 4.1 \\
\hline Potassium $\mathrm{K}_{2} \mathrm{O}$ (DS\%) & 0.8 & 2.1 \\
\hline
\end{tabular}

Since wastewater consists of comparatively much nitrogen, the fertilizer specifically influences foliage plants.

developing and developed countries [18]. Wastewater is a steady and reliable source of water that can conserve fertilizer costs. Contrary to clean water, wastewater flows do not vary with seasons, climatic conditions, or precipitation levels, thus allowing farmers to grow crops throughout the year. Furthermore, wastewater contains nutrients that can boost crop growth and reduce chemical fertilizer use. Compared with clean water irrigation, wastewater use can save up to $45 \%$ of fertilizer applied for wheat while the ratio can reach $94 \%$ for alfalfa [19]. Over $60 \%$ of the vegetables especially lettuce and onion are grown in urban areas using a mixture of groundwater and untreated wastewater in Dakar, Senegal. In developing countries, about 20 million hectares are irrigated with raw sewage or partially treated wastewater [20]. From figure 8 and table 2 , treated wastewater consists of comparatively much nitrogen. The anaerobic sludge when utilized as fertilizer specifically influences foliage plants.

\section{Conclusion}

DMR facilities for individual household wastewater demonstrated good performance of BOD removal with their effluent BOD less than $20 \mathrm{mg} / \mathrm{L}$. The quality of discharged water (treated water quality also showed good value and the standard deviation value) was also small. This indicates that the treatment by the filter material filled in the anaerobic filter bed was stable. It is an energy-efficient process that is usually employed to treat high-strength wastewater that is warm and contains high concentrations of biodegradable organic matter (measured as BOD, COD, and/or TSS). Japan's water treatment technology (Johkasou) has a high level and cost to maintain in normal treatment performance, maintenance operations are periodically adjusted and desludging them as necessary may not fit into the current economic level in some parts of developing countries, whereby stable electricity or running water infrastructure is not maintained. DMR which is cost effective with excellent performance, flexible, innovative anaerobic wastewater treatment recycling technology that is sustainable and adaptable installation will contribute its quota by assisting in proffering solution to achieve SDGs Target 6.3 by 2030, "improve water quality by eliminating dumping, minimizing release of hazardous chemicals and materials, untreated wastewater lessen to half proportion, reducing pollution, and substantially increasing recycling and safe reuse globally achieve" [13]. An anaerobic system can be used before polishing in an aerobic process for pretreatment prior to discharging to a municipal wastewater treatment plant. Anaerobic processes require little or no energy, fewer chemicals, and generate lower sludge handling costs compared to aerobic treatment options.

\section{References}

1. Mohammed AN, Elbably MA (2016) Technologies of Domestic Wastewater Treatment and Reuse: Options of Application in Developing Countries. JSM Environ Sci Ecol 4: 1033.
2. Rout SK (2013) Wastewater Treatment Technologies. Intl J Water Resources Environ Sci 2: 20-23.

3. Jimenez B, Mara D, Carr R, Brissaud F (2010) Wastewater treatment for pathogen removal and nutrient conservation: suitable systems for use in developing countries. International Water Management Institute, IWMI books, Reports, H042608.

4. Lettinga $G$ (2005) The anaerobic treatment approach towards a more sustainable and robust environmental protection. Water Sci Technol 52: 1-11.

5. Speece RE (1983) Anaerobic biotechnology for industrial wastewater treatment. Environ Sci Technol 17: 416A-427A.

6. Araujo DJ, Rocha SMS, Cammarota MC, Xavier AMF, Cardoso VL (2008) Anaerobic treatment of wastewater from the household and personal products industry in a hybrid. Braz J Chem Eng 25: 443-451.

7. Lohani SP, Chhetri A, Khanal SN (2015) A simple anaerobic system for onsite treatment of domestic wastewater. Afr J Environ Sci Technol 9: 292-300.

8. Lettinga $G$, de Man A, van der Last ARM, Wiegant W, van Knippenberg K, et al. (1993) Anaerobic Treatment of Domestic Sewage and Wastewater. Water Sci Technol 27: 67-73.

9. Nnaji CC (2014) A review of the upflow anaerobic sludge blanket reactor. Desalin water treat 52: 4122-4143.

10. Luostarinen S (2005) Anaerobic On-Site Wastewater Treatment at Low Temperatures. University of Jyvasklya, Finland.

11. Zeeman G, Lettinga G (1999) The role of anaerobic digestion of domestic sewage in closing the water and nutrient cycle at community level. Water Sci Technol 39: 187-194.

12. Lew B, Lustig I, Beliavski M, Tarre S, Green M (2011) An integrated UASB-sludge digester system for raw domestic wastewater treatment in temperate climates. Bioresour Technol 102: 49214924.

13. United Nations (2018) Sustainable Development Goal 6 Synthesis Report 2018 on Water and Sanitation. New York, USA.

14. Azimi AA, Zamanzadeh M (2004) Determination of design criteria for UASB reactors as a wastewater pretreatment system in tropical small communities. Int J Environ Sci Technol 1: 51-57.

15. Gaulke LS (2006) On-site wastewater treatment and reuses in Japan. Water Management 159: 103-109.

16. The popularization of wastewater treatment in Japan-2017.

17. Japan Global Center for Urban Sanitation (2011) Japanese Technology of Urban Sanitation. Urban Sanitation Study Group, Japan Institute of Wastewater Engineering Technology 3: 1-20.

18. Zhang Y, Shen $Y$ (2018) Wastewater irrigation : past, present, and future. WIREs Water 6: e1234.

19. Balkhair KS, El-Nakhlawi FS, Ismai SM, Al-Solimani SG (2013) Treated wastewater use and its effect on water conservation, vegetative yeild, yield components and water use efficiency of some vegetable crops grown under two different irrigation systems in western region, Saudi Arabia. $1^{\text {st }}$ Annual International Interdisciplinary Conference 395-402.

20. Drechsel P, Blumenthal UJ, Keraita B (2002) Balancing health and livelihoods: Adjusting wastewater irrigation guidelines for resourcepoor countries. Papers published in Journals (Open Access) 8: 7-9. 